\title{
CT-PI3: design, development, and place in therapy
}

This article was published in the following Dove Press journal:

Drug Design, Development and Therapy

6 June 2017

Number of times this article has been viewed

\author{
Tommaso Gabbani' \\ Simona Deiana ${ }^{2}$ \\ Vito Annese ${ }^{3}$ \\ 'Gastroenterology Unit, \\ Morgagni-Pierantoni Hospital, \\ AUSL Romagna, Forli, ${ }^{2}$ Division \\ of Gastroenterology, AOU Careggi \\ University Hospital, Florence, Italy; \\ ${ }^{3}$ Gastroenterology Department, \\ Valiant Clinic, Dubai, UAE
}

Correspondence: Vito Annese Gastroenterology Department, Valiant Clinic, P.O. Box 4I4296, Dubai, UAE

Tel +97l 509032048

Email vito.annese@valiant.ae
Abstract: The introduction of biological agents has revolutionized the management of many life-threatening and debilitating immune-mediated diseases. Because of the high cost of biological drugs and their patent expiration, the market has opened to biosimilar agents, copy versions of the originators, which can lead to reduced health care expenditure and increase treatment access worldwide. CT-P13 is the first biosimilar of infliximab (IFX) and has been approved for the same indications as its originator drug. It obtained regulatory approval by the European Medicines Agency in September 2013 and by the US Food and Drug Administration in April 2016. The Phase I and Phase III clinical trials conducted in ankylosing spondylitis and rheumatoid arthritis have demonstrated pharmacokinetic and efficacy equivalence with comparable safety and immunogenicity to IFX. For these reasons, the use of CT-P13 has been extrapolated also to inflammatory bowel disease. There have been some initial concerns regarding the use of CT-P13 in inflammatory bowel disease patients, because of the lack of randomized controlled trials. However, emerging real-world data have further confirmed the comparability between CT-P13 and its reference product in terms of efficacy, safety, and immunogenicity, in patients naïve to the anti-tumor necrosis factor alpha agents and after switching from IFX, and will be summarized in this review.

Keywords: CT-P13, infliximab, biosimilar, biologic therapy, Crohn's disease, ulcerative colitis

\section{Introduction}

Inflammatory bowel diseases (IBDs), which include Crohn's disease (CD) and ulcerative colitis (UC), are chronic immune-mediated inflammatory gastrointestinal disorders that lead to impaired quality of life, disease complications, and frequent surgery and hospitalization. ${ }^{1,2}$ They represent a global public health problem, and their prevalence is expected to increase because of the earlier age of onset and lower mortality rate of patients. Considering their social and economic long-term burden, the accurate control of these diseases is essential.

The introduction of biological therapies $>15$ years ago, such as the anti-tumor necrosis factor alpha (anti-TNF $\alpha$ ) monoclonal antibodies (mAbs), has led to the achievement of important therapeutic targets although increasing the direct costs. ${ }^{3}$ These treatments induce mucosal healing $(\mathrm{MH})$, prolonged periods of remission, and improve quality of life, leading to the reduction of hospitalizations and surgery. ${ }^{4}$ However, the high cost of biological drugs and their patent expiration have led to the development of biosimilar agents. ${ }^{5}$ They may lead to significant cost savings and consequently larger access to biologicals with affordable cost of care. ${ }^{6}$

CT-P13 has been the first mAb biosimilar evaluated by European Medicines Agency (EMA), and today over 34,000 patients in $>40$ countries worldwide have been treated with this drug. ${ }^{7}$ This review focuses on the development of the CT-P13 and on the main studies that have supported its use in IBD patients. 


\section{Biologics and biosimilars}

Biologics are defined as active substances derived from living cells or organisms with the aid of biotechnology methods (recombinant DNA, controlled gene expression, antibody technologies). ${ }^{8}$ The first generation of biologics was launched in the late 1970s and early 1980s, and this class of drugs is now one of the fastest growing sectors of the pharmaceutical industry. ${ }^{9}$ The high price of biological agents and their recent or impending patent expiration has led to development of similar versions of these drugs, called "biosimilar agents." The World Health Organization defines a biosimilar as a "biotherapeutic product which is similar in terms of quality, safety and efficacy to an already licensed reference biotherapeutic product." ${ }^{10}$ Biosimilars may differ from the original reference drug, in particular for post-translational modifications like glycosylation, which are specific to the individual production process, but differences are acceptable if the final molecule falls within defined "boundaries of tolerance": variations in some features of the 2 molecules are only considered important if they are clinically relevant. ${ }^{11,12}$ However, considering their size and complexity, biosimilars of biologic molecules require a more complex development and regulatory assessment than small-molecule generics to ensure that their safety and efficacy are similar to that of the original product. A comparability exercise is required to demonstrate biosimilarity. ${ }^{13,14}$ Approval of a biosimilar by the US Food and Drug Administration (FDA), Health Canada, and EMA includes extensive in vitro studies demonstrating similarity to a reference product in terms of quality features, as well as nonclinical and clinical studies demonstrating comparable pharmacokinetics, efficacy, safety, and immunogenicity. ${ }^{15-17}$ Subsequently, given that clinical efficacy of the reference drug has already been established, the nonclinical and clinical studies required for approval of a biosimilar could be reduced, and the extrapolation of data from one indication to another allows the approval for all indications held by the original drug. ${ }^{18,19}$ Indeed, EMA, FDA, and Health Canada have allowed the extrapolation, based on a number of comparability exercises although with no clinical data for all indications. ${ }^{20}$

\section{Infliximab (IFX; Remicade ${ }^{\mathrm{TM}}$ ) and its biosimilar agent CT-P I 3}

The anti-TNF $\alpha$ IFX was the first biologic agent used to treat IBD patients, and it is still widely used in these diseases. IFX is a chimeric human-murine $\mathrm{mAb}$ against the pro-inflammatory cytokine TNF $\alpha$. Several multicenter, randomized, doubleblind clinical trials have established the efficacy and safety of the IFX in the treatment of IBD. ${ }^{21-23}$ The management and the dosage of IFX in CD patients are supported by the results of the ACCENT I study, while the main experience with IFX in UC is based on the pivotal ACT trials; ACT I and ACT II demonstrated that IFX induces clinical remission, $\mathrm{MH}$, and steroid sparing in UC patients..$^{24,25}$

CT-P13 (Inflectra-Hospira, Lake Forest, IL, USA; and Remsima-Celltrion, Incheon, South Korea) is the first biosimilar agent of IFX. In 2012, it has been authorized for the treatment of autoimmune diseases and IBD in India and South Korea. ${ }^{26}$

CT-P13 has the same amino acid sequence, is produced by the same type of cell line (Sp2/0-AG1 purchased from ATCC, Manassas, VA, USA), and has the identical pharmaceutical form, composition, and same route of administration as the reference IFX. ${ }^{27}$ In the EU, South Korea, and Japan, CT-P13 received approval for the same therapeutic indications as reference IFX, including rheumatoid arthritis (RA), ankylosing spondylitis (AS), CD, UC, psoriatic arthritis, and psoriasis. ${ }^{28,29}$ In April 2016, CT-P13 was also approved for the treatment of IBD by the US FDA with the generic name IFX-dyyb, becoming also the first biosimilar $\mathrm{mAb}$ to be licensed in the US. ${ }^{30}$ The extrapolation to IBD was initially held by Health Canada because of differences between CT-P13 and IFX observed in vitro, potential differences in the mechanism of action of IFX in these conditions, and the lack of clinical studies, but has been recently approved. ${ }^{31,32}$

\section{Clinical and nonclinical evaluation of CT-P I 3}

Regulatory approval of CT-P13 was based on nonclinical and clinical comparisons with the IFX. As required by EMA, nonclinical evaluation includes pharmaco-toxicological analysis, while clinical evaluations include pharmacokinetic, pharmacodynamic, and efficacy studies and clinical safety studies also regarding the immunogenicity property of the biosimilar. ${ }^{33}$

\section{Nonclinical evaluation}

Several in vitro studies have demonstrated that CT-P13 and IFX have a comparable primary pharmacodynamic: CT-P13 and IFX showed very similar binding affinities for soluble monomeric and trimeric forms of TNF $\alpha$ and transmembrane TNF $\alpha$ and for the Fc $\gamma$ receptors Fc $\gamma R I$, Fc $\gamma R I I a$, and FcRN. ${ }^{34}$

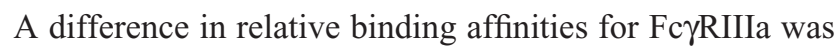
found, but after additional analysis with serum of CD patients, it was seen that the difference does not influence biological activity and does not have clinical relevance for 
the efficacy and safety of CT-P13. CT-P13 and IFX are also comparable in terms of the lack of binding activity to TNF $\beta$ and TNF $\alpha$ from different species known not to bind to infliximab and in terms of relative binding affinities to complement protein C1q. They are also comparable when considering complement-dependent cytotoxicity effects and apoptotic effects against a Jurkat T-cell line expressing TNF $\alpha$. Pharmacokinetic analysis comparing CT-P13 and IFX and repeat-dose toxicity studies of intravenous CT-P13 have been conducted in rats: the pharmacokinetics of 2 drugs at the doses of 10 and $50 \mathrm{mg} / \mathrm{kg}$ in rats were similar, and there were no toxicity concerns with CT-P13. ${ }^{35}$

Some minor differences, compared to IFX, including Fc $\gamma$ RIIIa receptor binding, the level of $\alpha$-fucosylation and some antibody-dependent cell-medicated cytotoxicity (ADCC), have been recorded. ${ }^{36}$ However, the initial differences observed on ADCC were only seen in vitro by using target cells overexpressing membrane TNF and by using enriched natural killer cells from $\mathrm{CD}$ patients with the highaffinity genotypes of the FcR. When ADCC activity was tested by using more physiologic cells, such as whole blood or isolated peripheral blood mononuclear cells, the difference in fucosylation for CT-P13 and the innovator drug did not impact ADCC; therefore, the clinical significance of these differences is questioned. ${ }^{37}$

\section{Clinical evaluation}

Data on the efficacy and safety of CT-P13 come from 2 randomized controlled trials (RCTs) in rheumatic disease, which demonstrated pharmacokinetic and efficacy equivalence and comparable safety and immunogenicity of CT-P13 and IFX in patients with active RA or AS. ${ }^{38-41}$

In the first (randomized, Phase I, double-blind) study (PLANETAS), efficacy and safety of CT-P13 and IFX $3 \mathrm{mg} / \mathrm{kg}$ were compared in 250 patients with AS. At 30 weeks, the pharmacokinetic profiles of the 2 agents (the primary outcome of the trial) were considered equivalent; CT-P13 and original IFX also displayed comparable efficacy and safety profiles.

The second (Phase III, double-blind) trial (PLANETRA) was conducted in 604 patients affected by RA with active disease despite methotrexate (MTX) treatment (12.5-25 $\mathrm{mg} /$ week). They were randomized to receive $3 \mathrm{mg} / \mathrm{kg}$ of CT-P13 (Remsima) $(\mathrm{n}=302)$ or IFX (n=302) with MTX and folic acid. At 30 weeks, the 2 treatment groups presented similar rates of the American College Rheumatology $20 \%$ responses (the primary end point of the trial), drugrelated adverse events, and anti-drug antibodies (ADAs).
Extension studies of these 2 RCTs have also demonstrated that the treatment efficacy, safety, and immunogenicity were not affected when patients were switched from reference product (RP) to CT-P13 at week 54 of treatment and followed up to week 102. ${ }^{42,43}$ However, the number of mild or moderate treatment-emergent adverse event and rate of ADAs seem to be slightly higher in patients switching therapy than in patients continuously treated with CT-P13 in AS patients and not in AR patients, suggesting that safety and immunogenicity after switching from an originator product to biosimilar could be influenced by different kinds of patient populations.

It is well known that immunogenicity is common in most biologics including IFX. It is associated with the loss of response, infusion reactions, and other adverse events. ${ }^{44}$ The degree of immunogenicity is not the same for all biologics, and only minor differences in the formulation, purity, or packaging of a biological drug can affect its immunogenicity profile. In both PLANETAS and PLANETRA studies, ADAs against CT-P13 and IFX were measured with similar findings for the 2 agents. During the extension phase, ADA incidence was comparable between maintenance and switch groups and did not increase significantly.

\section{CT-PI 3 in IBD}

The overall comparability testing of CT-P13 to IFX has led to the extrapolation of CT-P13 approval to all other indications for which reference IFX is approved, including IBD; however, when CT-P13 received the approval, its use in IBD was supported by data reported in the rheumatological trials and only by a small study of 25 IBD patients and some in vitro experiments. This has initially led to some concerns regarding the use of CT-P13 in IBD patients. It has been largely established that the efficacy of a biologic drug in IBD cannot be always predicted by effectiveness in other indications, such as RA. ${ }^{45}$ In addition, the dose of infliximab for IBD, $5 \mathrm{mg} / \mathrm{kg}$, is different from that used for $\mathrm{RA}, 3 \mathrm{mg} / \mathrm{kg}$. Moreover, biological drugs are more often used as monotherapy in IBD compared with rheumatic diseases. The concomitant use of MTX in the PLANETRA study may have reduced the risk of immunogenicity, compromising the validity of extrapolation of safety and efficacy data. Finally, the exact downstream effects of anti-TNF $\alpha$ agents in rheumatological diseases and in IBD are potentially different, and the immunogenicity of the biosimilar compared to originator could probably be different in different clinical settings. ${ }^{46}$ Regarding the mechanism of action, in RA IFX is thought to act predominantly through the neutralization 
of soluble and transmembrane TNF $\alpha$; in other diseases, like $\mathrm{CD}$, signaling through membrane-associated forms of TNF $\alpha$ and Fcg receptor (triggering apoptosis or ADCC) may play a more important role. ${ }^{47,48}$ For all these reasons, extrapolation across indications is not well established for biosimilars, and the following post-marketing studies have been crucial to provide useful insights into its efficacy and safety and to further support the use of CT-P13 in IBD patients.

\section{CT-P I 3: post-marketing experience in IBD}

An open-label, retrospective, multicenter study has evaluated the safety and the efficacy of CT-P13 (Remsima $\left.{ }^{\circledR}\right)$ in 173 patients with IBD in South Korea ${ }^{49}$ (Table 1). In total, 60 patients switched from the IFX to CT-P13 and 113 patients were biologic naïve. Treatment-related adverse events (TEAEs) occurred in 10\% of patients and were mostly mildto-moderate in severity, and no significant differences were observed in TEAE incidence between naïve patients and the switch group. The study reports positive outcomes for response and remission, confirming that CT-P13 was well tolerated and efficacious in patients with IBD.

Another retrospective multicenter study from South Korea has evaluated CD and UC patients treated with IFX biosimilar (both IFX-naïve patients and patients who switched to CT-P13 from its originator) by using Crohn's Disease Activity Index and partial Mayo score. ${ }^{50}$ In CD and UC IFX-naive patients, clinical response and remission were obtained in $85 \%$ and $58 \%$ at week 8 , in $93 \%$ and $62 \%$ at week 30 , and in $95 \%$ and $60 \%$ at week 54 , respectively. There was also a significant reduction in C-reactive protein (CRP) from baseline to week 30 in both the patient groups. After switching from IFX, the efficacy of CT-P13 was maintained in 93\% and $67 \%$ of CD and UC patients, respectively, and only $2 \mathrm{CD}$ patients and 1 UC patient stopped therapy after the switch because of lack of efficacy, suggesting that CT-P13 may be interchangeable with its originator in IBD patients.

A case series of 17 IBD patients (8 CD and 9 UC) has been conducted in a tertiary center in South Korea. ${ }^{51}$ Although the sample size was too small to allow statistical comparison and despite several limitations of this study, the results on the efficacy of CT-P13 are comparable to those of earlier controlled trials.

A prospective observational study was conducted in Czech Republic in 52 IBD patients treated with $5 \mathrm{mg} / \mathrm{kg}$ CT-P13 for up to 14 weeks: there were statistically significant improvements in Crohn's Disease Activity Index, and CRP serum levels after 14 weeks of therapy, and body weight increased, confirming the effectiveness of CT-P13 in IBD. ${ }^{52}$

Recently, a study has also evaluated the efficacy of CT-P13 induction therapy on MH in UC patients, demonstrating that $\mathrm{MH}$ is achieved in two-thirds of $\mathrm{UC}$ patients at the end of the induction treatment with CT-P13. ${ }^{53}$

Even if most of the reported studies demonstrate no differences between biosimilar IFX and the originator, contrasting data were reported by a single study in abstract form, which

Table I Clinical studies on CT-PI3 efficacy

\begin{tabular}{|c|c|c|c|c|}
\hline Study & Design & Number of patients & Disease & Assessment of efficacy \\
\hline Park et al, ${ }^{49}$ & Open-label, retrospective, multicenter & 173 & $95 \mathrm{CD}$ & CDAI, Mayo score \\
\hline (South Korea) & & & $78 \cup C$ & \\
\hline Jung et al,,$^{50}$ & Open-label, retrospective, multicenter & 110 & $59 \mathrm{CD}$ & CRP, CDAI, Mayo score \\
\hline (South Korea) & & & $5 I$ UC & \\
\hline Kang et al, ${ }^{51}$ & Open-label, case series, tertiary center & 17 & $8 \mathrm{CD}$ & CDAI, Mayo score \\
\hline (South Korea) & & & 9 UC & \\
\hline Keil et al, ${ }^{52}$ & Open-label, prospective, multicenter & 52 & $30 \mathrm{CD}$ & CDAI, Mayo score CRP \\
\hline (Czech Republic) & & & $22 \cup C$ & \\
\hline Farkas et al, ${ }^{53}$ & Open-label, prospective, multicenter & 63 & $63 \cup C$ & Mucosal healing with Mayo subscore \\
\hline (Czech Republic, Hungary) & & & & \\
\hline Gecse et al, ${ }^{55}$ & Open-label, prospective, observational, & 210 & $126 \mathrm{CD}$ & Mayo score, CRP, platelet count \\
\hline (Hungary) & multicenter & & $84 \cup C$ & \\
\hline Farkas et al, ${ }^{56}$ & Open-label, prospective, observational, & 39 & $18 \mathrm{CD}$ & CDAI, Mayo score \\
\hline (Hungary) & tertiary center & & $21 \cup C$ & \\
\hline Jahnsen et al, ${ }^{57}$ & Open-label, prospective, observational, & 78 & $46 \mathrm{CD}$ & Mayo score, CRP, calprotectin \\
\hline (Norway) & single center & & $32 \cup C$ & \\
\hline Schulze et al, ${ }^{58}$ & Open-label, prospective, multicenter & 86 IFX & IBD & Serum levels and drug antibodies \\
\hline (Germany) & & 33 CT-PI 3 & & \\
\hline Fiorino et al, ${ }^{60}$ & Open-label, prospective, multicenter, & 547 & $313 \mathrm{CD}$ & Mayo score \\
\hline (Italy) & tertiary center & & $234 \cup C$ & Harvey-Bradshaw \\
\hline
\end{tabular}

Abbreviations: CD, Crohn's disease; CDAl, Crohn's Disease Activity Index; UC, ulcerative colitis; CRP, C-reactive protein; IBD, inflammatory bowel disease; IFX, infliximab. 
has showed higher rates of surgery and more difficult disease control in patients treated with CT-P13 compared with those treated with IFX RP. However, the 2 cohorts included different kinds of patients in different study periods; rates of response and remission were not reported, and no descriptions of baseline characteristics are available. ${ }^{54}$

A Hungarian prospective, multicenter, observational study has evaluated 210 IBD (126 CD and 84 UC) patients. Twenty-two percentage of CD patients and $10 \%$ of UC patients had previously received therapy with the originator IFX, but not during the last 12 months. ${ }^{55}$ In this study, therapeutic drug levels were monitored, and ADAs were measured by using conventional and bridging enzyme-linked immunosorbent assay (ELISA) methods. This study showed that CT-P13 induces and maintains high clinical remission and response rates in both CD and UC patients up to week 30, while early response and remission rates were significantly different between patients previously exposed to the IFX as compared with the naïve patients. This was associated with significantly higher baseline ADA positivity in both CD and UC patients previously exposed to the originator drug. In conclusion, this study showed that patients with previous IFX exposure had a tendency toward lower early mean trough levels of the drug, decreased response rates, and more frequent allergic reactions.

Another Hungarian observational, prospective study has enrolled 39 IBD (18 CD and $21 \mathrm{UC}$ ) patients to evaluate efficacy, safety, and immunogenicity of CT-P13. ${ }^{56}$ Immunogenicity was determined in half of the patients by determination of serum IFX and ADA levels, and a significant difference was found between patients who had developed ADAs or not. The study reported a mild arthralgia and an anaphylactic reaction after the second infusion of CT-P13 in a patient with high ADA levels and previously treated with the originator IFX.

A prospective observational study performed in a single center in Norway has evaluated the efficacy, tolerability, and safety of CT-P13 in 78 patients with moderate-to-severe disease (46 CD, $32 \mathrm{UC}$ ). ${ }^{57} \mathrm{~A}$ total of 18 patients had previously been treated with TNF $\alpha$ inhibitors, without direct switching from IFX. In this study, CT-P13 was effective in both CD and UC patients, achieving similar clinical responses to those observed with the original IFX in large randomized studies, without unexpected adverse events. Immunogenicity, considered as the combination of ADA formation and a trough level of $0 \mathrm{mg} / \mathrm{L}$, was seen in 8 patients ( $4 \mathrm{CD}$ and $4 \mathrm{UC}$ ), and it led to discontinuation of treatment in 7 patients.

A German single-center study has evaluated the role of drug monitoring in IBD patients treated with biosimilar of
IFX; this study included 86 IBD patients treated with IFX and 33 treated with CT-P13. ${ }^{58}$ In the study, CT-P13 serum levels, IFX serum levels, and ADA serum levels were measured in both groups to investigate the possible differences in antidrug immunogenicity. No significant differences in anti-drug immunogenicity in patients receiving Remsima or Inflectra and Remicade have been demonstrated, thus confirming the feasibility of drug monitoring in IBD patients treated with the IFX biosimilar CT-P13. Another recent study has demonstrated that anti-Remicade antibodies in IBD patients recognize and functionally inhibit Remsima to a similar degree, suggesting similar immunogenicity profile. ${ }^{59}$

Recently, the clinical outcome of 547 IBD consecutive patients (313 CD and $234 \mathrm{UC}$ ) enrolled from 31 referral centers has been reported; 311 patients were naive to anti-TNF $\alpha$ agents, 139 had a previous exposure to biologics, and the remaining 97 were switched to CT-P13 after a mean of $18 \pm 14$ infusions of IFX. ${ }^{60}$ The mean follow-up was $4.3 \pm 2.8$ months, and the total follow-up time was 195 patient-years. The efficacy of the biosimilar was evaluated in 434 patients who received treatment for at least 8 weeks, by using time-to-event methods for censored observations: 35 patients were primary failures (8.1\%). After further 8, 16, and 24 weeks, the efficacy estimations were $95.7 \%, 86.4 \%$, and $73.7 \%$ for naive; $97.2 \%$, $85.2 \%$, and $62.2 \%$ for pre-exposed; and $94.5 \%, 90.8 \%$, and $78.9 \%$ for switch, respectively (log-rank $P=0.64$ ). Sixty-six serious adverse events were reported (12.1\%), 38 (6.9\%) of them were infusion-related reactions. Although no direct comparison was performed, preliminary data of the largest cohort of IBD patients treated with CT-P13 described so far demonstrate that the efficacy and safety were in line with those of IFX.

\section{Switching and alternation of biosimilars}

Following approval of biosimilars, it was important to evaluate the possibility to alternate or switch from the original product to the biosimilar or vice versa in clinical practice or also to switch between different biosimilars. However, concepts of interchangeability and switchability have not been sufficiently studied not only in the context of biosimilars but also with originator biologics in general.

According to the US FDA, an interchangeable biological product refers to a biosimilar that "meets additional standards for interchangeability" and "may be substituted for the reference product by a pharmacist without the intervention of the health care provider." ${ }^{61}$ Currently, no biosimilar agents have received approval for "interchangeable" status and 
interchangeability cannot be supported for any biosimilar. The "interchangeability" should be distinguished from the "transition" or switching that is the physician's decision to switch between a reference biologic (RP) and its biosimilar, or vice versa. With regard to single switching from original drug to biosimilar CT-P13 during maintenance therapy, positive evidence came from clinical trials and real-world cohorts, demonstrating no new safety signals or immunogenicity changes. In contrast, multiple repeated transitions between a RP and its biosimilar or other biosimilars of the same RP are not recommended due to lack of data about the safety.

The effects of switching to CT-P13 from original IFX have been investigated in a small prospective observational study from Poland in 39 pediatric IBD patients (32 $\mathrm{CD}, 7 \mathrm{UC}){ }^{62}$ In the $\mathrm{CD}$ group, $69 \%$ were in remission at the time of switching and $31 \%$ had mild-to-moderate disease activity. After a further mean follow-up period of 8 months after switching, $88 \%$ of the patients were in clinical remission. Remission was also observed in some UC patients, although this subgroup was too small for reliable efficacy comparisons. Adverse event rate did not differ significantly before and after the switch from IFX to CT-P13. This study has several limitations such as the small sample size, the heterogeneity of time of switching during therapy, and the great variation in length of the individual follow-up period, but it demonstrates that switching from IFX to CT-P13 seems to be well tolerated in children with CD (Table 2). ${ }^{60,63-65}$

The Norway government have commissioned a clinical trial, the NOR-SWITCH study (ClinicalTrials.gov NCT02148640), which is a randomized, double-blind, parallel-group, noninferiority study that compares the originator IFX with CT-P13 in patients with 6 immune-mediated inflammatory diseases, including RA, spondyloarthritis, psoriatic arthritis, UC, CD, and chronic plaque psoriasis. ${ }^{66}$ This study assesses the safety, efficacy, and the immunogenicity of continued originator IFX treatment compared to the switching from originator IFX to CT-P13 in about 500 patients with immune-mediated disease. Patients enrolled have been in a stable remission with IFX RP for at least 6 months prior to inclusion; then they receive an equivalent dose of CT-P13 or continue to receive originator IFX for additional 52 weeks. The primary study end point is disease worsening that is defined in CD as an increase in Harvey Bradshaw Index of $\geq 4$ points from randomization and a minimum HBI score of 7 points and in UC as an increase in partial Mayo score of $\geq 3$ points from randomization and a minimum partial Mayo score of $\geq 5$ points. The preliminary results were presented during the recent United European Gastroenterology Week in Vienna: all reported end points (disease worsening, incidence of ADAs, frequency of adverse events) have confirmed the noninferiority of the biosimilar versus the originator. ${ }^{67}$ However, the NOR-SWITCH study has significant design limitations. The variety of included patients is both a strength of the study, with results applicable to a larger number of patients and diseases which already represent an indication of the drug. However, this variety is also a weakness. The study lacks clarity in definitions, including inclusion/exclusion criteria, end points, and use and impact of concomitant medications.

\section{Ongoing studies - Phase III}

Some Phase III studies of CT-P13 in IBD patients are still ongoing. A randomized parallel-group, Phase III study (ClinicalTrials.gov identifier: NCT02096861) should be completed in February 2017, and it will investigate the efficacy and the safety of CT-P13 in patients with

Table 2 Summary of published studies reporting the outcome of patients switched from infliximab to CT-PI3

\begin{tabular}{|c|c|c|c|c|}
\hline Study/authors & Disease of interest & $\begin{array}{l}\text { Number of } \\
\text { patients }\end{array}$ & Evaluation of efficacy & $\begin{array}{l}\text { Evaluation of } \\
\text { safety after switch }\end{array}$ \\
\hline PLANETAS ${ }^{39}$ & Ankylosing spondylitis & 86 & Similar efficacy & $\begin{array}{l}\text { Comparable safety } \\
\text { and immunogenicity }\end{array}$ \\
\hline PLANETRA $^{41}$ & Rheumatoid arthritis & 144 & Similar efficacy & $\begin{array}{l}\text { Comparable safety } \\
\text { and immunogenicity }\end{array}$ \\
\hline Park et al ${ }^{49}$ & IBD & $40 \mathrm{CD}, 16 \cup C$ & $81 \%$ CD, $45.5 \% \cup C$ & Not specified \\
\hline Jung et $\mathrm{al}^{50}$ & IBD & $27 \mathrm{CD}, 9 \cup \mathrm{UC}$ & $93 \%$ CD, 67\% UC & Not specified \\
\hline Kang et $\mathrm{al}^{51}$ & IBD & $5 \mathrm{CD}, 4 \cup \mathrm{UC}$ & $89 \%$ & Not specified \\
\hline Nikiphorou et al ${ }^{64}$ & Rheumatoid arthritis & 39 & $\begin{array}{l}\text { No statistical difference for } \\
\text { symptoms and lab tests }\end{array}$ & No difference \\
\hline Fiorino et $\mathrm{al}^{60}$ & IBD & $53 \mathrm{CD}, 44 \mathrm{UC}$ & $79 \%$ at 32 weeks & No difference \\
\hline Sieczkowska et $\mathrm{al}^{62}$ & Paediatric IBD & 32 CD, 7 UC & $80 \%$ CD, $100 \%$ UC & No difference \\
\hline
\end{tabular}

Abbreviations: IBD, inflammatory bowel disease; CD, Crohn's disease; UC, ulcerative colitis. 
active CD. A global registry study in IBD has also been initiated (ClinicalTrials.gov identifier: NCT02326155), and it will be completed in 2026 . The study is recruiting adults or children aged $\geq 6$ years with active $C D$ and adults with fistulizing CD or UC. The main aim is to monitor the safety of CT-P13 in IBD patients, but efficacy and health economic parameters will also be assessed during the study.

\section{Conclusion}

CT-P13 has been largely evaluated in immune-mediated diseases, particularly in rheumatologic diseases, where it has demonstrated its equivalency in terms of efficacy and safety compared to the original product Remicade. Its adoption can lead, as for the other biosimilar agents, to cost savings with larger access to biological therapies. Emerging results from prospective observational studies support the short-term clinical efficacy and safety of CT-P13 in patients with IBD, including those who switched from the originator IFX. However, implementation of national registries of IBD patients on biological therapies and prospective long-term real-world data on clinical efficacy and safety are awaited.

\section{Acknowledgments}

The authors sincerely thank Dr Andrew Jamieson MB $\mathrm{ChB}$ (Hons) BSc(Hons) PhD FRCPGlasg for a careful review of English text for syntax, grammar, and spelling mistakes.

\section{Author contributions}

SD performed literature search and wrote the first draft; TG performed literature research, wrote and reviewed the article; VA designed and coordinated the review, and revised the final draft of the manuscript. All authors contributed toward data analysis, drafting and critically revising the paper and agree to be accountable for all aspects of the work.

\section{Disclosure}

The authors report no conflicts of interest in this work.

\section{References}

1. Solberg IC, Lygren I, Jahnsen J, et al; IBSEN Study Group. Clinical course during the first 10 years of ulcerative colitis: results from a population-based inception cohort (IBSEN Study). Scand J Gastroenterol. 2009;44:431-440.

2. Solberg I, Vatn M, Hoie O, et al; IBSEN Study Group. Clinical course in Crohn's disease: results of a Norwegian population-based ten-year follow-up study. Clin Gastroenterol Hepatol. 2007;5: 1430-1438.

3. Danese S, Vuitton L, Peyrin-Biroulet L. Biological agents for IBD: practical insights. Nat Rev Gastroenterol Hepatol. 2015;12:537-545.
4. Annese V, Duricova D, Gower-Rousseau C, Jess T, Langholz E. Impact of new treatments on hospitalisation, surgery, infection, and mortality in IBD: a focus paper by the Epidemiology Committee of ECCO. J Crohns Colitis. 2016;10(2):216-225.

5. Scheinberg MA, Kay J. The advent of biosimilar therapies in rheumatology - "O brave new world". Nat Rev Rheumatol. 2012;8: 430-436.

6. Jha A, Upton A, Dunlop WC, Akehurst R. The budget impact of biosimilar infliximab $\left(\right.$ Remsima $\left.{ }^{\circledR}\right)$ for the treatment of autoimmune diseases in five European countries. Adv Ther. 2015;32(8):742-756.

7. Jahnsen J. Clinical experience with infliximab biosimilar Remsima (CT-P13) in inflammatory bowel disease patients. Therap $A d v$ Gastroenterol. 2016;9(3):322-329.

8. Weise M, Bielsky MC, De Smet K, et al. Biosimilars: what clinicians should know. Blood. 2012;120(26):5111-5117.

9. Schneider CK, Vleminckx C, Gravanis I, et al. Setting the stage for biosimilar monoclonal antibodies. Nat Biotechnol. 2012;30:1179-1185.

10. World Health Organization. Expert Committee on Biological Standardization. Guidelines on Evaluation of Similar Biotherapeutic Products; 2009. Available from: http://www.who.int/biologicals/areas/biological_therapeutics/BIOTHERAPEUTICS_FOR_WEB_22APRIL2010. pdf. Accessed February 28, 2016.

11. U.S. Food and Drugs Administration [webpage on the Internet]. Demonstration of comparability of human biological products, including therapeutic biotechnology-derived products. Available from: http:// www.fda.gov/Drugs/GuidanceComplianceRegulatoryInformation/ Guidances/ucm122879.htm. Accessed April 4, 2016.

12. International Conference on Harmonisation. Q5E Comparability of Biotechnological/Biological Products Subject to Changes in their Manufacturing Process. Available from: http://www.ich.org/fileadmin/ Public_Web_Site/ICH_Products/Guidelines/Quality/Q5E/Step4/ Q5E_Guideline.pdf. Accessed April 4, 2016.

13. US Food and Drug Administration [webpage on the Internet]. Biosimilars; 2015 [cited Dec 7, 2015]. Available from: http://www.fda.gov/Drugs/ DevelopmentApprovalProcess/HowDrugsareDevelopedandApproved/ ApprovalApplications/TherapeuticBiologicApplications/Biosimilars. Accessed December 1, 2016.

14. European Medicines Agency [webpage on the Internet]. Biosimilar medicines; 2015 [cited Dec 7, 2015]. Available from: http://www.ema. europa.eu/ema/index.jsp?curl=pages/special_topics/document_listing/ document_listing_000318.jsp. Accessed December 1, 2016.

15. Committee for Medicinal Products for Human Use, European Medicines Agency. Guideline on similar biological medicinal products containing monoclonal antibodies - non-clinical and clinical issues. EMA/ CHMP/BMWP/403543/2010; 2012. Available from: http://www.ema. europa.eu/docs/en_GB/document_library/Scientific_guideline/2012/06/ WC500128686.pdf. Accessed September 4, 2013.

16. Health Products and Food Branch, Health Canada. Guidance for sponsors: information and submission requirements for subsequent entry biologics (SEBs); 2010. Available from: http://www.hc-sc.gc.ca/dhp$\mathrm{mps} /$ brgtherap/applic-demande/guides/biosimilars-biosimilaires-eng. php. Accessed February 4, 2014.

17. U.S. Food and Drug Administration. Guidance for industry: scientific considerations in demonstrating biosimilarity to a reference product (draft guidance); 2012. Available from: http://www.fda.gov/downloads/ Drugs/GuidanceComplianceRegulatoryInformation/Guidances/ UCM291128.pdf. Accessed February 4, 2014.

18. Ebbers HC. Biosimilars: in support of extrapolation of indications. J Crohns Colitis. 2014;8(5):431-435.

19. Weise M, Kurki P, Wolff-Holz E, Bielsky M, Schneider C. Biosimilars: the science of extrapolation. Blood. 2014;124:3191-3196.

20. Feagan BG, Choquette D, Ghosh S, et al. The challenge of indication extrapolation for infliximab biosimilars. Biologicals. 2014;42: $177-183$.

21. Lemann M, Mary J, Duclos B, et al. Infliximab plus azathioprine for steroid-dependent Crohn's disease patients: a randomized placebocontrolled trial. Gastroenterology. 2006;130:1054-1061. 
22. Colombel J, Sandborn W, Reinisch W, et al; Groupe d'Etude Therapeutique des Affections Inflammatoires du Tube Digestif (GETAID). Infliximab, azathioprine, or combination therapy for Crohn's disease. N Engl J Med. 2010;362:1383-1395.

23. Panaccione R, Ghosh S, Middleton S, et al. Combination therapy with infliximab and azathioprine is superior to monotherapy with either agent in ulcerative colitis. Gastroenterology. 2014;146:392-400, e393.

24. Hanauer S, Feagan B, Lichtenstein G, et al; ACCENT I Study Group. Maintenance infliximab for Crohn's disease: the ACCENT I randomised trial. Lancet. 2002;359:1541-1549.

25. Rutgeerts P, Sandborn W, Feagan B, et al. Infliximab for induction and maintenance therapy for ulcerative colitis. N Engl J Med. 2005;353: 2462-2476.

26. Evaluate ${ }^{\mathrm{TM}}$ [webpage on the Internet]. KFDA approves Remsima(TM) (infliximab), the world's first antibody biosimilar [press release]. Celltrion, Johnson \& Johnson; 2012 [July 23]. Available from: http://www. evaluategroup.com/Universal/View.aspx .type=Story\&id=320129. Accessed December 1, 2016.

27. European Medicines Agency. Committee for Medicinal Products for Human Use (CHMP). Assessment report: Inflectra (infliximab); 2013. Available from: http://www.ema.europa.eu/docs/en_GB/ document_library/EPAR__Public_assessment_report/human/002778/ WC500151490.pdf. Accessed February 17, 2014.

28. Generics and biosimilars initiative online [webpage on the Internet]. Biosimilars approved in South Korea; 2015. Available from: http:// gabionline.net/Biosimilars/General/Biosimilars-approved-in-SouthKorea. Accessed December 1, 2016.

29. Generics and biosimilars initiative online [webpage on the Internet]. Biosimilars approved in Japan; 2015. Available from: http://gabionline. net/Biosimilars/General/Biosimilars-approved-in-Japan. Accessed December 1, 2016.

30. INFLECTRA' [prescribing information]. Available from: http://www. accessdata.fda.gov/drugsatfda_docs/label/2016/125544s000lbl.pdf. Accessed April 11, 2016.

31. Health Canada [webpage on the Internet]. Summary basis of decision for Remsima; 2014. Available from: http://www.hc-sc.gc.ca/dhp-mps/ prodpharma/sbd-smd/index-eng.php. Accessed February 28, 2016.

32. CADTH. CADTH Canadian drug expert committee final recommendation: infliximab (Inflectra - Hospira Healthcare Corporation) Indications: Crohn Disease and Ulcerative Colitis; 2016. Available from: https://www.cadth.ca/sites/default/files/cdr/complete/SE0483_ IBD_Inflectra-Oct-28-16.pdf. Accessed December 1, 2016.

33. European Medicines Agency. Committee for Medicinal Products for Human Use (CHMP). Guideline on similar biological medicinal products containing biotechnology-derived proteins as active substance: non-clinical and clinical issues. Draft; 2013. Available from: http://www.ema.europa.eu/docs/en_GB/document_library/ Scientific_guideline/2013/06/WC500144124.pdf. Accessed February 17, 2014.

34. Appendix A PLANETAS study Ann Rheum Dis; 2013. Available from: http://ard.bmj.com.gate2.inist.fr/content/suppl/2013/05/16/ annrheumdis-2012-203091.DC1/annrheumdis-2012-203091supp_ appendixA.pdf. Accessed July 11, 2013.

35. European Medicines Agency. Committee for Medicinal Products for Human Use (CHMP). Assessment report: Inflectra (infliximab); 2013. Available from: http://www.ema.europa.eu/docs/en_GB/ document_library/EPAR_-_Public_assessment_report/human/002778/ WC500151490.pdf. Accessed February 17, 2014.

36. Summary basis of decision (SBD) for Remsima [webpage on the Internet]. Health Canada Web site. Available from: http://www.hc-sc.gc.ca/ dhp-mps/prodpharma/sbd-smd/index-eng.php. Published April 1, 2014. Accessed April 9, 2014.

37. European Medicines Agency. Committee for Medicinal Products for Human Use (CHMP). Assessment report: inflectra. Available from: http://www.ema.europa.eu/docs/en_GB/document_library/ EPAR_-_Public_assessment_report/human/002778/WC500151490. pdf. Published June 27, 2013. Accessed December 2, 2014.
38. Park W, Hrycaj P, Jeka S, et al. A randomised, double-blind, multicentre, parallel-group, prospective study comparing the pharmacokinetics, safety, and efficacy of CT-P13 and innovator infliximab in patients with ankylosing spondylitis: the PLANETAS study. Ann Rheum Dis. 2013;72:1605-1612.

39. Park W, Yoo DH, Jaworski J, et al. Comparable long-term efficacy, as assessed by patient reported outcomes, safety and pharmacokinetics, of CT-P13 and reference infliximab in patients with ankylosing spondylitis: 54-week results from the randomized, parallel-group PLANETAS study. Arthritis Res Ther. 2016;18:25.

40. Yoo DH, Hrycaj P, Miranda P, et al. A randomised, double-blind, parallel-group study to demonstrate equivalence in efficacy and safety of CT-P13 compared with innovator infliximab when coadministered with methotrexate in patients with active rheumatoid arthritis: the PLANETRA study. Ann Rheum Dis. 2013;72: $1613-1620$

41. Yoo DH, Racewicz A, Brzezicki J, et al. A phase III randomized study to evaluate the efficacy and safety of CT-P13 compared with reference infliximab in patients with active rheumatoid arthritis: 54-week results from the PLANETRA study. Arthritis Res Ther. 2016;18:82.

42. Park W, Yoo DH, Miranda P, et al. Efficacy and safety of switching from reference infliximab to CT-P13 compared with maintenance of CT-P13 in ankylosing spondylitis: 102-week data from the PLANETAS extension study. Ann Rheum Dis. 2017;76(2):346-354.

43. Yoo DH, Prodanovic N, Jaworski J, et al. Efficacy and safety of CT-P13 (biosimilar infliximab) in patients with rheumatoid arthritis: comparison between switching from reference infliximab to CT-P13 and continuing CT-P13 in the PLANETRA extension study. Ann Rheum Dis. 2017;76(2):355-363.

44. Allez M, Karmiris K, Louis E, et al. Report of the ECCO pathogenesis workshop on anti-TNF therapy failures in inflammatory bowel diseases: definitions, frequency and pharmacological aspects. J Crohn's Colitis. 2010;4:355-366.

45. Gecse KB, Khanna R, van den Brink GR, et al. Biosimilars in IBD: hope or expectation? Gut. 2013;62:803-807.

46. Ben-Horin S, Heap GQ, Ahmad T, et al. The immunogenicity of biosimilar infliximab: can we extrapolate the data across indications? Expert Rev Gastroenterol Hepatol. 2015;9(Suppl 1):27-34.

47. Van den Brande JM, Koehler TC, Zelinkova Z, et al. Prediction of anti tumour necrosis factor clinical efficacy by real- time visualisation of apoptosis in patients with Crohn's disease. Gut. 2007;56(4): 509-517.

48. Tilg H, Moschen A, Kaser A. Mode of function of biological anti-TNF agents in the treatment of inflammatory bowel diseases. Expert Opin Biol Ther. 2007;7(7):1051-1059.

49. Park S, Kim Y, Lee J, et al. Post-marketing study of biosimilar infliximab (CT-P13) to evaluate its safety and efficacy in Korea. Expert Rev Gastroenterol Hepatol. 2015;9:35-44.

50. Jung YS, Park DI, Kim YH, et al. Efficacy and safety of CT-P13, a biosimilar of infliximab, in patients with inflammatory bowel disease: a retrospective multicenter study. $J$ Gastroenterol Hepatol. 2015; 30(12):1705-1712.

51. Kang Y, Moon H, Lee S, Lim Y, Kang H. Clinical experience of the use of CT-P13, a biosimilar to infliximab in patients with inflammatory bowel disease: a case series. Dig Dis Sci. 2015;60:951-956.

52. Keil R, Wasserbauer M, Zádorová Z, et al. Clinical monitoring: infliximab biosimilar CT-P13 in the treatment of Crohn's disease and ulcerative colitis. Scand J Gastroenterol. 2016;51(9):1062-1068.

53. Farkas K, Rutka M, Golovics PA, et al. Efficacy of infliximab biosimilar CT-P13 induction therapy on mucosal healing in ulcerative colitis. J Crohns Colitis. 2016;10(11):1273-1278.

54. Murphy C, Sugrue K, Mohamad J, et al. Biosimilar but not the same. J Crohns Colitis. 2015;9(Suppl 1):S331-S332 (P505).

55. Gecse K, Lovasz B, Farkas K, et al. Efficacy and safety of the biosimilar infliximab CT-P13 treatment in inflammatory bowel diseases: a prospective, multicentre, nationwide cohort. JCrohn's Colitis. 2015;10(2): 133-140. 
56. Farkas K, Rutka M, Balint A, et al. Efficacy of the new infliximab biosimilar CT-P13 induction therapy in Crohn's disease and ulcerative colitis - experiences from a single center. Expert Opin Biol Ther. 2015;15: 1257-1262.

57. Jahnsen J, Detlie T, Vatn S, Ricanek P. Biosimilar infliximab (CT-P13) in the treatment of inflammatory bowel disease: a Norwegian observational study. Expert Rev Gastroenterol Hepatol. 2015;9:45-52.

58. Schulze K, Koppka N, Lutter F, Brandhorst G, Schreiber S, Helwig U. CT-P13(Inflectra ${ }^{\mathrm{TM}}$, Remsima ${ }^{\mathrm{TM}}$ ) monitoring in patients with inflammatory bowel disease. Biologicals. 2016;44(5):463-466.

59. Ben-Horin S, Yavzori M, Benhar I, et al. Cross-immunogenicity: antibodies to infliximab in Remicade-treated patients with IBD similarly recognise the biosimilar Remsima. Gut. 2016;65(7):1132-1138.

60. Fiorino G, Manetti N, Armuzzi A, et al. The PROSIT-BIO cohort: a prospective observational study of patients with inflammatory bowel disease treated with infliximab biosimilar. Inflamm Bowel Dis. 2017;23:233-243.

61. U.S. Food and Drugs Administration [webpage on the Internet]. Information on biosimilars. Available from: http://www.fda.gov/Drugs/Development ApprovalProcess/HowDrugsareDevelopedandApproved/ApprovalApplications/TherapeuticBiologicApplications/Biosimilars/default.htm. Accessed March 25, 2016.

62. Sieczkowska J, Jarzębicka D, Banaszkiewicz A, et al. Switching between infliximab originator and biosimilar in pediatric patients with inflammatory bowel disease: preliminary observation. J Crohn's Colitis. 2015;10(2):127-132.
63. Braun J, Kudrin A. Switching to biosimilar infliximab (CT-P13): evidence of clinical safety, effectiveness and impact on public health. Biologicals. 2016;44(4):257-266.

64. Nikiphorou E, Kautiainen H, Hannonen P, et al. Clinical effectiveness of CT-P13 (infliximab biosimilar) used as a switch from Remicade (infliximab) in patients with established rheumatic disease. Report of clinical experience based on prospective observational data. Expert Opin Biol Ther. 2015;15:1677-1683.

65. Fiorino G, Manetti N, Armuzzi A, et al. The PROSIT-BIO Cohort: A prospective observational study of patients with inflammatory bowel disease treated with infliximab biosimilar. Inflam Bowel Dis. 2017;23(2):233-243.

66. BioPharma. Norway to facilitate switch to biosimilars with $\$ 3 \mathrm{~m}$ Remicade study. http://www.biopharma-reporter.com/Markets-Regulations/Norwayto-facilitate-switch-to-biosimilars-with-3m-Remicadestudy; 2013. Accessed January 7, 2016.

67. Jørgensen K et. 'LB15 - Biosimilar infliximab (CT-P13) is not inferior to originator infliximab: results from the 52-week randomized NORSWITCH trial.' Abstract presented at the United European Gastroenterology (UEG) Week meeting 2016, 15-19 October, Vienna, Austria.

\section{Publish your work in this journal}

Drug Design, Development and Therapy is an international, peerreviewed open-access journal that spans the spectrum of drug design and development through to clinical applications. Clinical outcomes, patient safety, and programs for the development and effective, safe, and sustained use of medicines are the features of the journal, which

\section{Dovepress}

has also been accepted for indexing on PubMed Central. The manuscript management system is completely online and includes a very quick and fair peer-review system, which is all easy to use. Visit http://www.dovepress.com/testimonials.php to read real quotes from published authors.

Submit your manuscript here: http://www.dovepress.com/drug-design-development-and-therapy-journal 